Research Article

Dian M. Setiawan*

\title{
The role of temperature differential and subgrade quality on stress, curling, and deflection behavior of rigid pavement
}

https://doi.org/10.1515/jmbm-2020-0010

Received Dec 21, 2019; accepted Aug 17, 2020

\begin{abstract}
To determine performance of rigid pavement, pavement engineers should not only conduct stress, curling, and deflection analysis, but also understand weather conditions and subgrade quality effects on rigid pavement performance well. This study aims to analyze and visualize the mechanical behaviors of rigid pavement in terms of stress, curling, and deflection using the KENPAVE Program under different curling temperature and subgrade quality. Besides, this study also evaluated temperature differential and k-value effects on the stress, curling, and deflection behavior of concrete pavement. The findings revealed that there is a linear correlation between stress and both k-value and curling temperature, with the latter having more significant impact in controlling stress than the former. However, even though curling is not affected by subgrade quality, it significantly depends on the temperature differential since a higher curling temperature produces higher curling behavior. Lastly, a higher temperature differential produces greater deflection, but a higher $\mathrm{k}$-value produces smaller deflection. Nevertheless, deflection behavior has a more significant curve and the position of the highest deflection shifted towards the center of the slab as the curling temperature and subgrade quality increase.
\end{abstract}

Keywords: curling, deflection, KENPAVE, modulus of subgrade reaction, rigid pavement, stress

\section{Introduction}

In this modern era, the phenomenon of increasing environmental heat become a crucial issue. It is characterized by a

\footnotetext{
*Corresponding Author: Dian M. Setiawan: Department of Civil Engineering, Universitas Muhammadiyah Yogyakarta, Bantul, 55183, Special Region of Yogyakarta, Indonesia;

Email: diansetiawanm@ft.umy.ac.id
}

higher temperature in dense regions such as an urban area compared to the surrounding rural areas [1]. According to Solecki et al. [2] and Romeo and Zinzi [3] in Carpio et al. [1], a high percentage of shortwave solar radiation could be absorbed by concrete materials during the day. Moreover, during the summer season, solar radiation tends to be stored and evaporative cooling tends to be blocked by concrete pavement [4-6]. Such a condition can affect the properties of concrete materials in rigid pavement.

A study on the application of reflective pavement in an urban square with a total area of $4,500 \mathrm{~m}^{2}$, in Athens (Greece) had been reported by [7]. They revealed that there was a reduction in air temperature in the square by $1.9^{\circ} \mathrm{C}$ on a summer's day due to the application of cool pavement. At the same time, the surface temperature decreased by $12^{\circ} \mathrm{C}$. Moreover, according to [6], temperature distribution across a pavement slab is affected more by the daily temperature amplitude during the daytime rather than during night-time. Pavement in areas with more significant daily temperature amplitude experience higher negative temperature gradients during the night-time hours.

Temperature has a significant effect on the design and performance of both rigid and flexible pavement. Variations in temperature within a pavement structure contribute to pavement distress and possible failure in several ways [6]. A study into the effect of temperature is necessary to determine the type and frequency of maintenance required throughout the service life of a pavement structure. Pavement's structural performance are extremely reliant on the temperature to which they are exposed. In establishing thermal stress and design parameters of flexible pavement and rigid pavement, daily and seasonal variations in the maximum, minimum, average, and gradient temperature across the pavement depth need to be considered. The principal element is not the actual temperature at or near the surface, but the temperature gradients within the slab that can create cracks in the rigid pavement slab [8-12] and rutting in the asphalt pavement [13]. Significant thermal stress and deformations in the concrete pavement with laterally-fixed concrete slabs can result from daily change

○ Open Access. (c) 2020 D. M. Setiawan, published by De Gruyter. (CC) BY 4.0 License 
in temperature. This stress is vital for the dimensioning of pavement and is significantly contingent on concrete slab temperature difference [14]. In rigid pavement, stress caused by environmental factors such as temperature is much more critical compared to in flexible pavement. This stress can be calculated easily after determining environmental and materials properties. However, semi-static nature makes them complicated to superimpose on dynamic traffic stresses [15].

In concrete slab pavement, temperature difference between the top and bottom of the PCC layer results in temperature gradients across the concrete slab depth, which in turn leads to a tendency to curl and differential expansions [11, 16, 17]. Concrete slab weight controls this curling tendency, making thermal stress induced in concrete materials. Vehicle load stress, together with thermal stress, may produce cracking in the pavement structure. Furthermore, in case of curling stress due to a positive thermal gradient, a critical stress condition will occur in a rigid pavement. A positive thermal gradient means that the surface temperature is higher than the temperature at the bottom [11, 18]. Also, Shoukry et al. [19] and Siddique et al. [20] in Hernandez and Al-Qadi [21] found that curling resulting from a positive temperature differential is slightly higher than that caused by a negative one.

According to Mackiewicz [14], curling stress occurs due to linear thermal difference in the whole thickness of the slab. He also assumed that temperature remains constant in the typical middle plane of the pavement, whereas temperature at the top of the slab is different from that at the bottom. To obtain the overall stress of the slab due to temperature variations, these two primary components of thermal stress are combined using algebraic addition.

Regarding the solution for temperature curling, Westergaard [22, 23] has assumed a linear temperature change through the depth of concrete pavement slabs [24]. However, in contrast to Westergaard's research outputs, other authors concluded that the actual temperature profiles through the rigid slab thickness are nonlinear [24-27]. Moreover, Choubane and Tia [28] recommended to consider the non-linear temperature distribution throughout the whole concrete slab thickness rather than temperature difference between extreme slab fibres.

A model to analyze the impact of non-linear temperature distribution had been developed by [29]. Although temperature difference between the top and bottom surfaces of pavement slabs is the fundamental parameter in the analysis of linear temperature distribution, they concluded that the real temperature distribution along the slab depth was more important to analyze the effect of temperature variation.
According to O'Mahony et al. [30], there are differences in bearing capacity, deformability, and stability of weak foundations such as peat soil under changing time frames and weather conditions. These variations will pose a considerable challenge to the maintenance and serviceability of rigid pavement structures constructed on weak soil. Roads on peat foundations will deform easily under vehicle loading, which speeds up their degradation and enforces high maintenance and rehabilitation costs. Furthermore, previous studies conducted by Joshi et al. [8] have shown that for particular joint spacing and rigid slab thickness, a higher modulus of subgrade reaction can result in higher curling stress due to temperature difference. Higher curling stress can lead to higher loading and curling stress in pavement.

Finite element modeling of flexible pavement on soft soil subgrades had been developed by [31] to study the effect of wheel pressure and configuration, as well as axle load variations of a standard truck on the mechanical performance of flexible road pavement with a thin asphalt surfacing layer. They concluded that a finite element method could be used to assess potential distress efficiently. Finite element simulation could be conducted as well to analyze pavement under response to various parameters [32? -34]. In the last two decades, there are several 2- and 3dimensional finite element models developed and used around the world, such as KENPAVE [36, 37], ISLAB [33], ILLI-SLAB [37-40], JSLAB [41], WESLAYER [42], FEACONS IV [43, 44], and ISLAB2000 [45].

KENSLAB program was developed by Huang [46] and simulates slabs using 2D medium-thick plate elements as either beam elements or linear and torsion springs. Even though the program can neither simulate stress distribution through the depth of the slab nor include a non-linear gradient, it helps pavement engineers to visualize the mechanical behavior of a pavement structure by some modification and additional work and it supports computer programs such as Microsoft Excel that can provide a 3dimensional graphical design. In a rigid pavement system, stress and deflection analysis is essential to determine the response of the structure due to loading (curling, corner, interior, and edge).

\section{Curling temperature}

Due to variation in temperature between the top and bottom of a concrete slab, curling stress develops along rigid pavement (Figure 1). Even though curling stress may not be as significant as vehicular loading stress, it usually re- 
sults in increased cracking potential and, therefore, reduces pavement serviceability $[21,23]$.

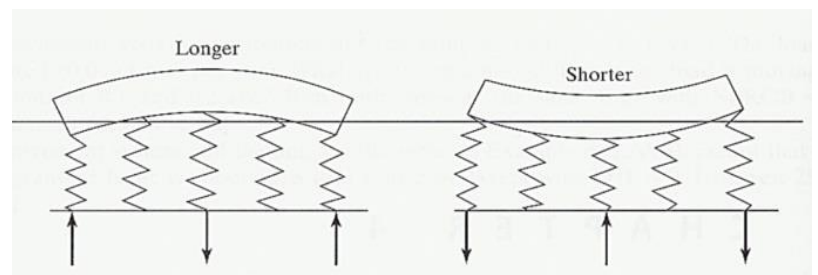

(a) Downward Curling

(b) Upward Curling

Figure 1: Curling condition in rigid pavement: (a) Negative temperature gradient, the temperature at the top $<$ temperature at the bottom; and (b) positive temperature gradient, the temperature at the Top > temperature at the bottom

\section{Modulus of subgrade reaction (k-Value)}

The k-value is an essential design input that describes the response of the subgrade material $[19,47]$. It is defined as:

$$
k=-p / \Delta
$$

Where a foundation of width " $\mathrm{b}$ " is subject to a load per unit area of " $p$ " and the corresponding settlement is " $\Delta$ ". The value of $k$ can be stated in pci or $\mathrm{kN} / \mathrm{m}^{3}$ and depends on several factors like the length, width, and depth of the foundation. Therefore, the k-value is not constant for soil $[19,47,48]$.

In this study, the analysis was conducted by assuming that the temperature change through the depth of concrete pavement is linear, and using a positive temperature differential. The analysis was also conducted by assuming that the type of foundation is liquid foundation based on the $\mathrm{k}$-value (modulus of subgrade reaction).

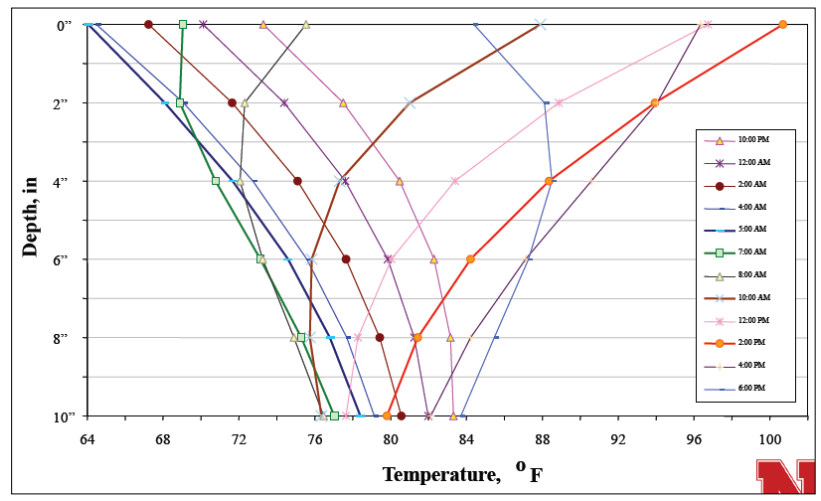

Figure 2: PCC temperature profile [49]

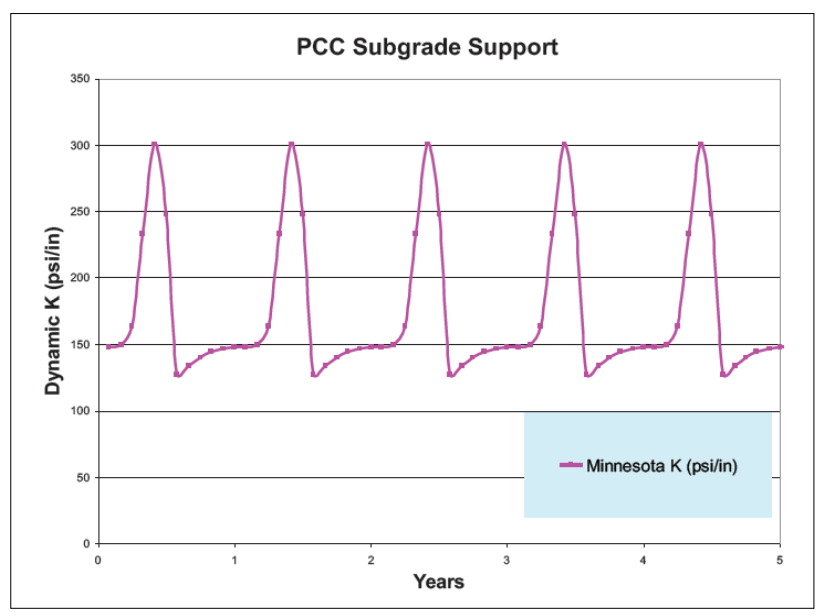

Figure 3: Soil property (k-Value) adjustment [49]

As can be seen in Figures 2 and 3 above, the PCC temperature profile and soil properties (k-value) change over time. Temperature and moisture gradients in the top PCC layer can significantly affect stress and deflection, and result in damage and distress in the pavement. Also, k-value will be higher in the winter season and lower in the summer season. Pavement engineers need to understand the behavior of rigid pavement by considering different PCC temperature profiles and k-values. Therefore, this study aims to visualize the mechanical behaviors of rigid pavement using KENPAVE Program (stress, curling, and deflection behavior) under various temperature differentials, $\Delta \mathrm{T}$ $\left(10^{\circ} \mathrm{F}, 20^{\circ} \mathrm{F}, 30^{\circ} \mathrm{F}\right)$ and different subgrade qualities, $\mathrm{k}(100$ pci, 200 pci, and 300 pci) in order to gain more understanding of the effects of the temperature differential and modulus of subgrade reaction on the stress, curling, and deflection behavior of concrete pavement.

However, this study only considered stress and deflection due to Interior Loading and Curling and does not consider stress due to Friction as well as joints, steel reinforcements, tie bars, dowel bars, and the gap that may happen between the bottom of the slab and the subgrade when exposed to curling temperature. Therefore, in this study there is no loss of subgrade support.

\section{Research method}

This study used 10-inch thick slabs supported by a subgrade with modulus of subgrade reaction, $\mathrm{k}$. A dualtandem wheel load (of 9,800 lb each) was applied to the interior of the slab, as shown in Figure 5 below. The contact pressure is 80 psi. Assume that the Young's modulus 
is 4,000,000 psi, Poisson's ratio for the slab is 0.15 , and $\alpha_{t}$ $=5 \times 10^{-6} \mathrm{in} / \mathrm{in} /{ }^{\circ} \mathrm{F}$.

The following table (Table 1) shows nine (9) combinations of the modulus of subgrade reaction $(\mathrm{k})$ and temperature difference $(\Delta \mathrm{T})$ for the KENPAVE analysis.

Table 1: Combinations for KENPAVE Analysis

\begin{tabular}{cccc}
\hline $\mathbf{k} \boldsymbol{\&} \mathbf{\Delta} \mathbf{T}$ & $\mathbf{1 0 ^ { \circ }} \mathbf{F}$ & $\mathbf{2 0 ^ { \circ }} \mathbf{F}$ & $\mathbf{3 0 ^ { \circ }} \mathbf{F}$ \\
\hline $100 \mathrm{pci}$ & $10^{\circ} \mathrm{F} \& 100 \mathrm{pci}$ & $20^{\circ} \mathrm{F} \& 100 \mathrm{pci}$ & $30^{\circ} \mathrm{F} \& 100 \mathrm{pci}$ \\
$200 \mathrm{pci}$ & $10^{\circ} \mathrm{F} \& 200 \mathrm{pci}$ & $20^{\circ} \mathrm{F} \& 200 \mathrm{pci}$ & $30^{\circ} \mathrm{F} \& 200 \mathrm{pci}$ \\
$300 \mathrm{pci}$ & $10^{\circ} \mathrm{F} \& 300 \mathrm{pci}$ & $20^{\circ} \mathrm{F} \& 300 \mathrm{pci}$ & $30^{\circ} \mathrm{F} \& 300 \mathrm{pci}$ \\
\hline
\end{tabular}

Figure 4 presents the contact area between tires and the pavement surface and its equivalent contact area.
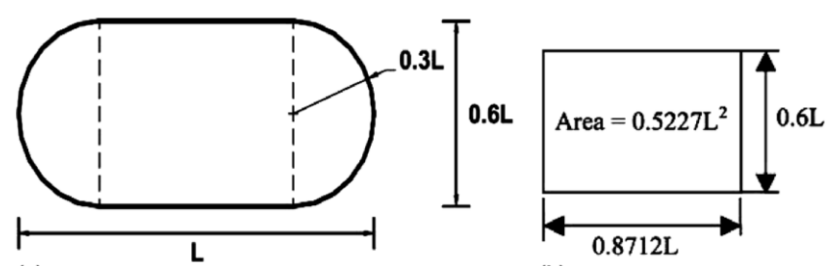

(a)

(b)

Figure 4: (a) Contact area between tires and the pavement surface; (b) equivalent contact area $[46,50]$

Since L is 15.30 in, 1 wheel has the rectangular area conversion of $0.5227 \mathrm{~L}^{2}$, with a length of 13.3 and a width of $9.2 \mathrm{in}$. This study also considered the wheel configuration based on truck class 9. Moreover, the wheel configuration on the slab and part of the slab that modeled in KENSLAB (inside the red rectangle) can be seen in Figure 5. Besides, Figure 6 presents data on load areas for each wheel.

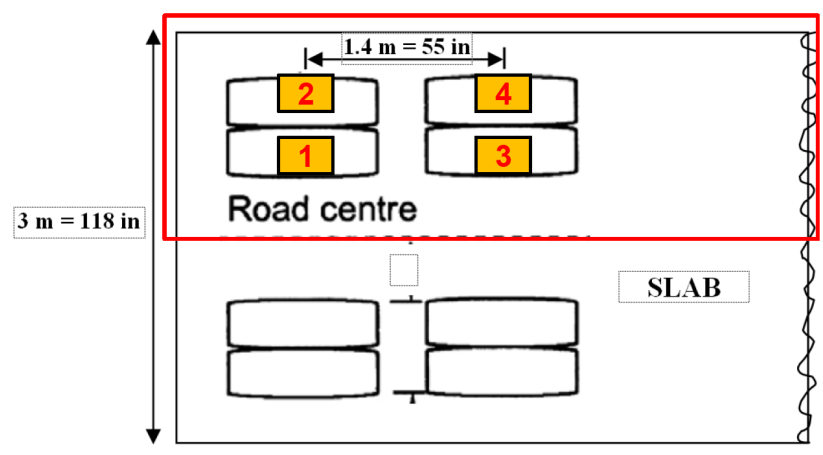

Figure 5: Wheel configuration on the slab [50]

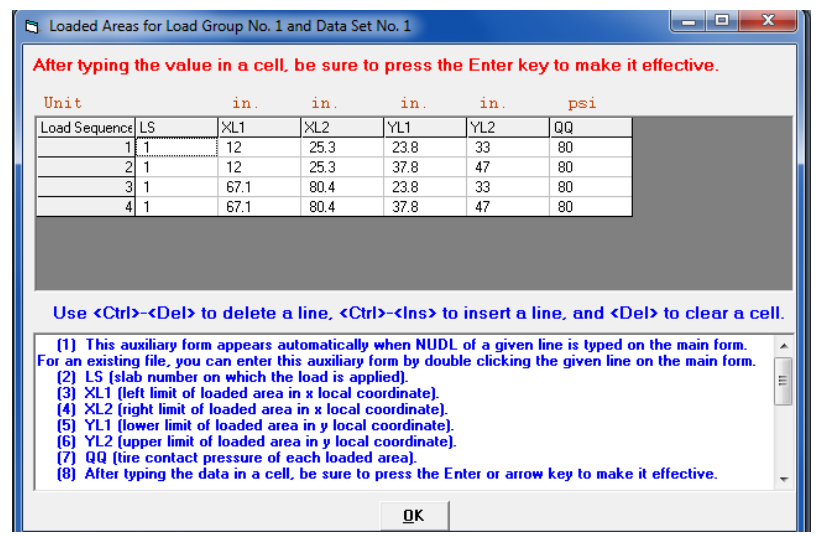

Figure 6: Data on load areas in KENSLAB

\section{Results and discussion}

Figure 7 presents the slab design and wheel configuration in KENSLAB as well as the highest stress position in each row of nodes (red points).

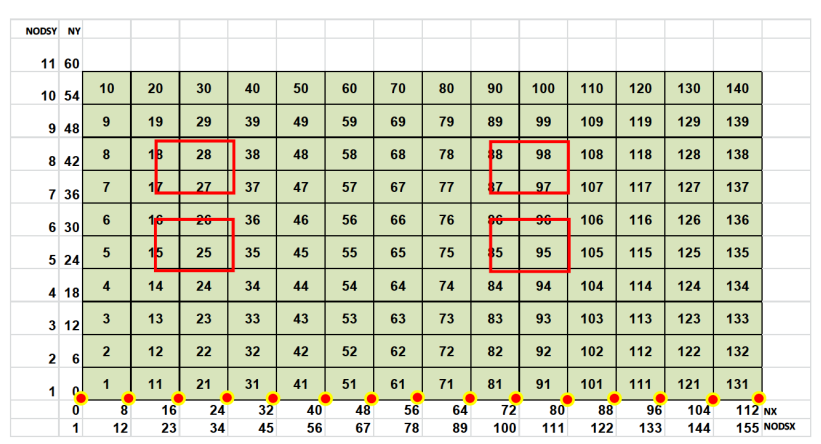

Figure 7: Slab design, wheel configuration in KENSLAB, and the highest stress position in each row of nodes

As illustrated in Figure 8 (a-f), there are two peaks in each line. These two peaks are below the wheel positions. Furthermore, in Figure 8a, a k-value of 100 pci and an increase in the curling temperature by $10^{\circ} \mathrm{F}$ (i.e. from $10^{\circ} \mathrm{F}$ to $20^{\circ} \mathrm{F}$ and from $20^{\circ} \mathrm{F}$ to $30^{\circ} \mathrm{F}$ ) will cause stress to rise by approximately $14 \mathrm{psi}$. For example, from $150 \mathrm{psi}\left(10^{\circ} \mathrm{F}\right)$ to 164 psi $\left(20^{\circ} \mathrm{F}\right)$ and from $164 \mathrm{psi}\left(20^{\circ} \mathrm{F}\right)$ to $178 \mathrm{psi}\left(30^{\circ} \mathrm{F}\right)$. Then, a k-value of $200 \mathrm{pci}$ and an increase in the curling temperature by $10^{\circ} \mathrm{F}$ will cause stress to rise by approximately $25-26$ psi (Figure 8c). Lastly, a k-value of 300 pci and an increase in the curling temperature by $10^{\circ} \mathrm{F}$ will cause stress to rise by approximately $35 \mathrm{psi}$ (Figure 8e). Also, a higher k-value tends to result in a greater gap between the lines.

In Figure $8 \mathrm{~b}$, a curling temperature of $10^{\circ} \mathrm{F}$ and an increase in the k-value by 100 pci (i.e. from 100 pci to 200 


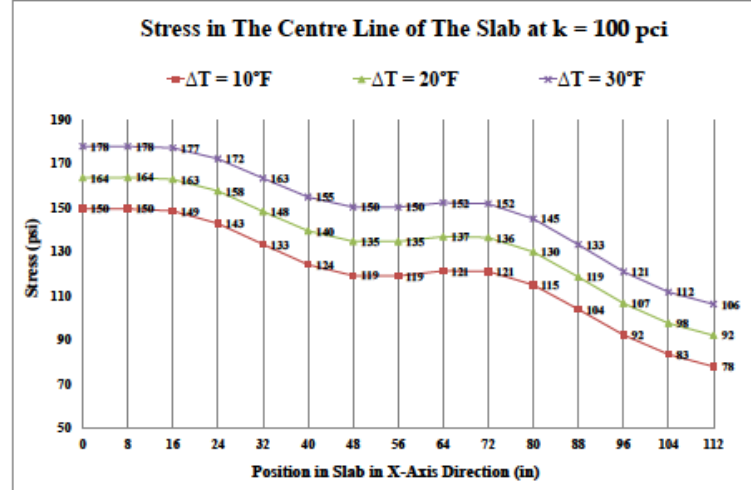

(a)

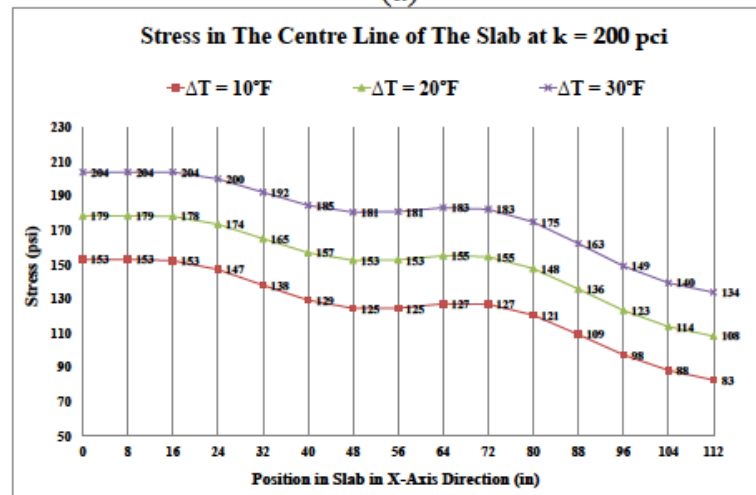

(c)

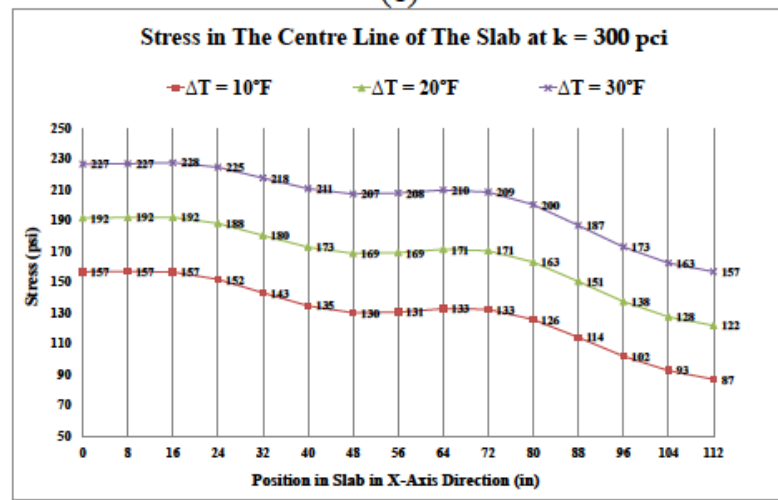

(e)

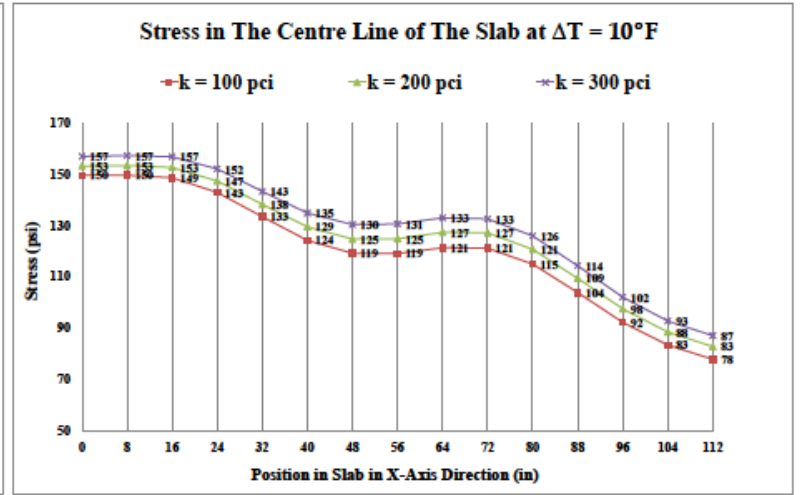

(b)

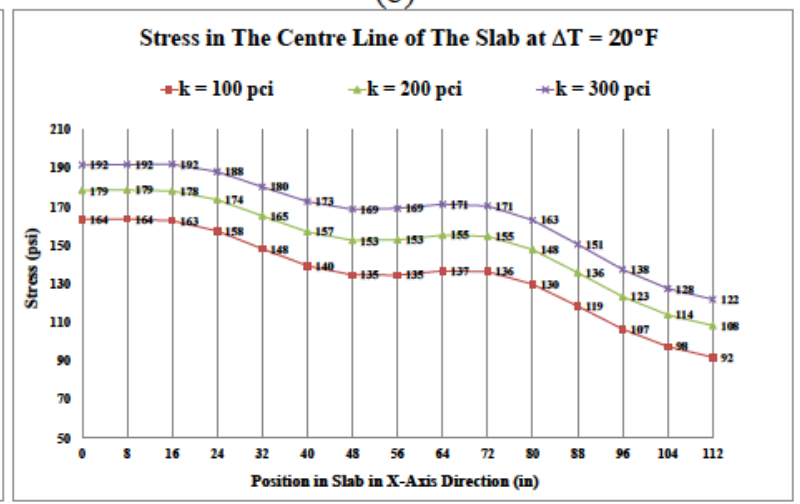

(d)

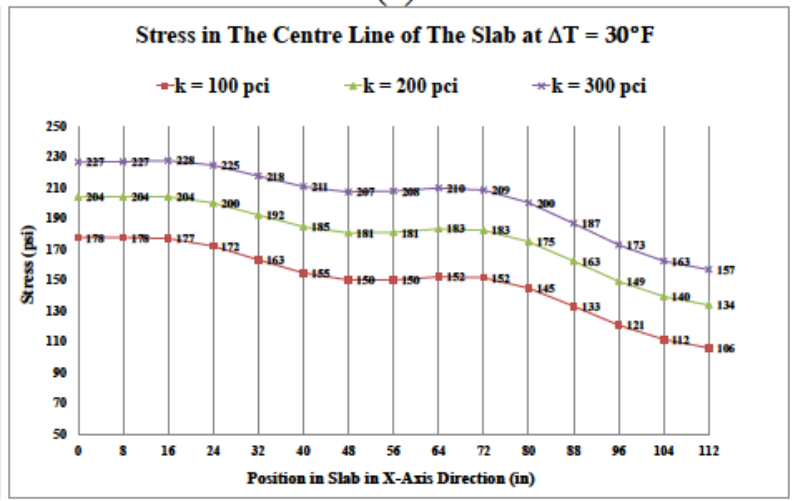

(f)

Figure 8: Stress in the center line of the slab

pci and from 200 pci to 300 pci) will result in increased stress by approximately 3-4 psi, meaning that stress rises from 150 psi to 153 psi in the event of an increased k-value from 100 pci to 200 pci and, likewise, it rises from 153 psi to $157 \mathrm{psi}$ in the event of an increased k-value from $200 \mathrm{pci}$ to $300 \mathrm{pci}$. Then, a curling temperature of $20^{\circ} \mathrm{F}$ and an increase in the k-value by 100 pci will cause stress to rise by approximately 13-15 psi (Figure 8d). Lastly, a curling temperature of $30^{\circ} \mathrm{F}$ and an increase in the k-value by $100 \mathrm{pci}$ will lead to increased stress by approximately $23-26 \mathrm{psi}$ (Figure $8 \mathrm{f}$ ). Besides, a higher curling temperature leads to a greater gap between the lines.
Table 2: Combinations for KENPAVE analysis

\begin{tabular}{cccc}
\hline $\mathbf{k} \boldsymbol{\&} \mathbf{\Delta} \mathbf{T}$ & $\mathbf{1 0}^{\circ} \mathbf{F}$ & $\mathbf{2 0}^{\circ} \mathbf{F}$ & $\mathbf{3 0}^{\circ} \mathbf{F}$ \\
\hline $100 \mathrm{pci}$ & $150 \mathrm{psi}$ & $164 \mathrm{psi}$ & $178 \mathrm{psi}$ \\
$200 \mathrm{pci}$ & $153 \mathrm{psi}$ & $179 \mathrm{psi}$ & $204 \mathrm{psi}$ \\
$300 \mathrm{pci}$ & $157 \mathrm{psi}$ & $192 \mathrm{psi}$ & $228 \mathrm{psi}$ \\
\hline
\end{tabular}

Figure 9 exhibits the line graph for all combinations of curling temperature and $\mathrm{k}$-value, while Table 2 shows the summary of the highest stress in rigid pavement for each combination. It can be concluded that stress in rigid pave- 


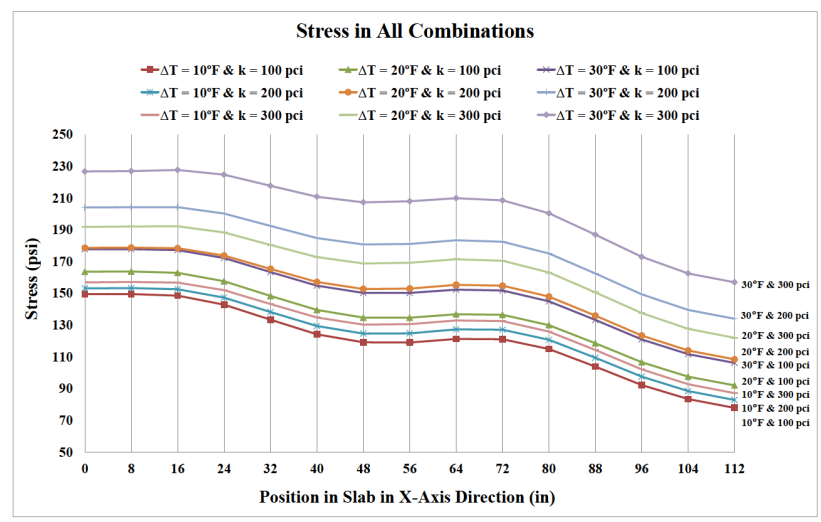

Figure 9: Stress for all combinations of curling temperature and $k$-Value

Table 3: Comparisons of curling

\begin{tabular}{cccc}
\hline $\mathbf{k} \boldsymbol{\&} \mathbf{\Delta} \mathbf{T}$ & $\mathbf{1 0 ^ { \circ }} \mathbf{F}$ & $\mathbf{2 0}^{\circ} \mathbf{F}$ & $\mathbf{3 0}^{\circ} \mathbf{F}$ \\
\hline $100 \mathrm{pci}$ & 0.01684 & 0.03368 & 0.05052 \\
$200 \mathrm{pci}$ & 0.01684 & 0.03368 & 0.05052 \\
$300 \mathrm{pci}$ & 0.01684 & 0.03368 & 0.05052 \\
\hline
\end{tabular}

ment is affected by both the modulus of subgrade reaction and curling temperature. Based on Figure 9 and Table 2, the highest stress was generated in the simulation with $\mathrm{k}$ $=300$ pci and $\Delta \mathrm{T}=30^{\circ} \mathrm{F}$, while the lowest stress was generated in the simulation with $\mathrm{k}=100 \mathrm{pci}$ and $\Delta \mathrm{T}=10^{\circ} \mathrm{F}$.

The following discussion concerns curling analysis and visualizations. Figure 10 illustrates the results of curling analysis using the same k-value for three different curling temperatures. At first, the k-value used amounted to 100 pci. By increasing the curling temperature from $10^{\circ} \mathrm{F}$ to $20^{\circ} \mathrm{F}$, the curling behavior will rise from 0.01684 inch to $0.03368 \mathrm{inch}$. Then, an increase in the curling temperature from $20^{\circ} \mathrm{F}$ pci to $30^{\circ} \mathrm{F}$ will raise the curling behavior from 0.03368 inch to 0.05052 inch. More results of the curling analysis using the same k-value (200 pci and $300 \mathrm{pci}$ ) and different $\Delta \mathrm{T}\left(10^{\circ} \mathrm{F}, 20^{\circ} \mathrm{F}\right.$, and $\left.30^{\circ} \mathrm{F}\right)$ can be seen in Table 3 , where the results show the same increment. The results accord with the findings of [14] that a higher $\Delta \mathrm{T}$ results in greater curling.

Figure 11 shows the output of the curling analysis using the same curling temperature of $10^{\circ} \mathrm{F}$ for three different k-values (i.e. 100 pci, 200 pci, and 300 pci). In the first simulation, the three different $k$-values showed the same curling behavior, i.e. 0.01684 inch, at the same curling temperature of $10^{\circ} \mathrm{F}$. More results of the curling analysis at the same $\Delta \mathrm{T}\left(20^{\circ} \mathrm{F}\right.$ and $\left.30^{\circ} \mathrm{F}\right)$ with different k-values (100, 200, and 300 pci) can be seen in Table 3 , which suggest that $\Delta \mathrm{T}$ at $20^{\circ} \mathrm{F}$ and $30^{\circ} \mathrm{F}$ produce a higher curling value than the previous $\Delta \mathrm{T}$ at $10^{\circ} \mathrm{F}$, but the curling value is the same for a k-value of 100,200 , and 300 pci at $\Delta \mathrm{T}$ of $20^{\circ} \mathrm{F}$ and $30^{\circ} \mathrm{F}$.

Table 3 displays the summary of the highest curling condition in each combination. An increase in the temperature difference from $10^{\circ} \mathrm{F}$ to $20^{\circ} \mathrm{F}$ will increase curling behavior two times. Then, an increase in the temperature difference from $10^{\circ} \mathrm{F}$ to $30^{\circ} \mathrm{F}$ will increase curling behavior three times.

Figure 12 presents results of the deflection analysis and visualizations. Initially, the analysis focused on the use of the same k-value for three different curling temperatures. The first simulation used a k-value of 100 pci and increased the curling temperature from $10^{\circ} \mathrm{F}$ to $20^{\circ} \mathrm{F}$, which resulted in increased deflection from 0.0811 inch in the $1^{\text {st }}$ row to 0.0819 inch in the $2^{\text {nd }}$ row (an increase of $1 \%$ ). Then, using the same $\mathrm{k}$-value, the curling temperature was increased from $20^{\circ} \mathrm{F}$ pci to $30^{\circ} \mathrm{F}$, which generated increased deflection from 0.0819 inch in the $2^{\text {nd }}$ row to 0.0835 inch in the $3^{\text {rd }}$ row (an increase of $2 \%$ ). More results of the deflection analysis at the same k-value (200 pci and $300 \mathrm{pci}$ ) with different $\Delta \mathrm{T}\left(10^{\circ} \mathrm{F}, 20^{\circ} \mathrm{F}\right.$, and $\left.30^{\circ} \mathrm{F}\right)$ can be seen in Table 4, where the results show different increments. As for the simulation with a k-value of 200 pci and an increase in the curling temperature from $10^{\circ} \mathrm{F}$ to $20^{\circ} \mathrm{F}$, it led to an increase in deflection from $0.0392 \mathrm{inch}$ in the $2^{\text {nd }}$ row to $0.0409 \mathrm{inch}$ in the $4^{\text {th }}$ row (an increase of $4.3 \%$ ). Then, the curling temperature was raised from $20^{\circ} \mathrm{F}$ pci to $30^{\circ} \mathrm{F}$, which also resulted in increased deflection from 0.0409 inch in the $4^{\text {th }}$ row to 0.0444 inch in the $5.5^{\text {th }}$ row (an increase of $8.6 \%$ ). Lastly, a k-value of 300 pci with an increase in the curling temperature from $10^{\circ} \mathrm{F}$ to $20^{\circ} \mathrm{F}$ increased the deflection from 0.0256 inch in the $3.5^{\text {th }}$ row to 0.0285 inch in the $5.5^{\text {th }}$ row (an increase of $11.3 \%$ ). Then, the curling temperature was raised from $20^{\circ} \mathrm{F}$ pci to $30^{\circ} \mathrm{F}$ and it generated increased deflection from 0.0285 inch in the $5.5^{\text {th }}$ row to 0.0322 inch in the $6^{\text {th }}$ row (an increase of 13\%). The results agree with [14], that a higher $\Delta \mathrm{T}$ generates greater deflection.

Figure 13 shows results of the deflection analysis and visualizations using the same curling temperature for three different $k$-values. The first simulation used a curling temperature of $10^{\circ} \mathrm{F}$. An increased k-value from 100 pci to 200 pci reduced deflection from 0.0811 inch in the $1^{\text {st }}$ row to 0.0392 inch in the $2^{\text {nd }}$ row (a reduction of $51.7 \%$ ). Then, an increase in the k-value from 200 pci to 300 pci reduced deflection from 0.0392 inch in the $2^{\text {nd }}$ row to 0.0256 inch in the $3.5^{\text {th }}$ row (a reduction of $34.7 \%$ ). More results of the deflection analysis at the same $\Delta \mathrm{T}\left(20^{\circ} \mathrm{F}\right.$ and $\left.30^{\circ} \mathrm{F}\right)$ with different k-values $(100,200$, and 300 pci) can be seen in Table 4, where the results show different decrements. As for the simulation using a curling temperature of $20^{\circ} \mathrm{F}$ and an increase in the k-value from 100 pci to 200 pci caused 


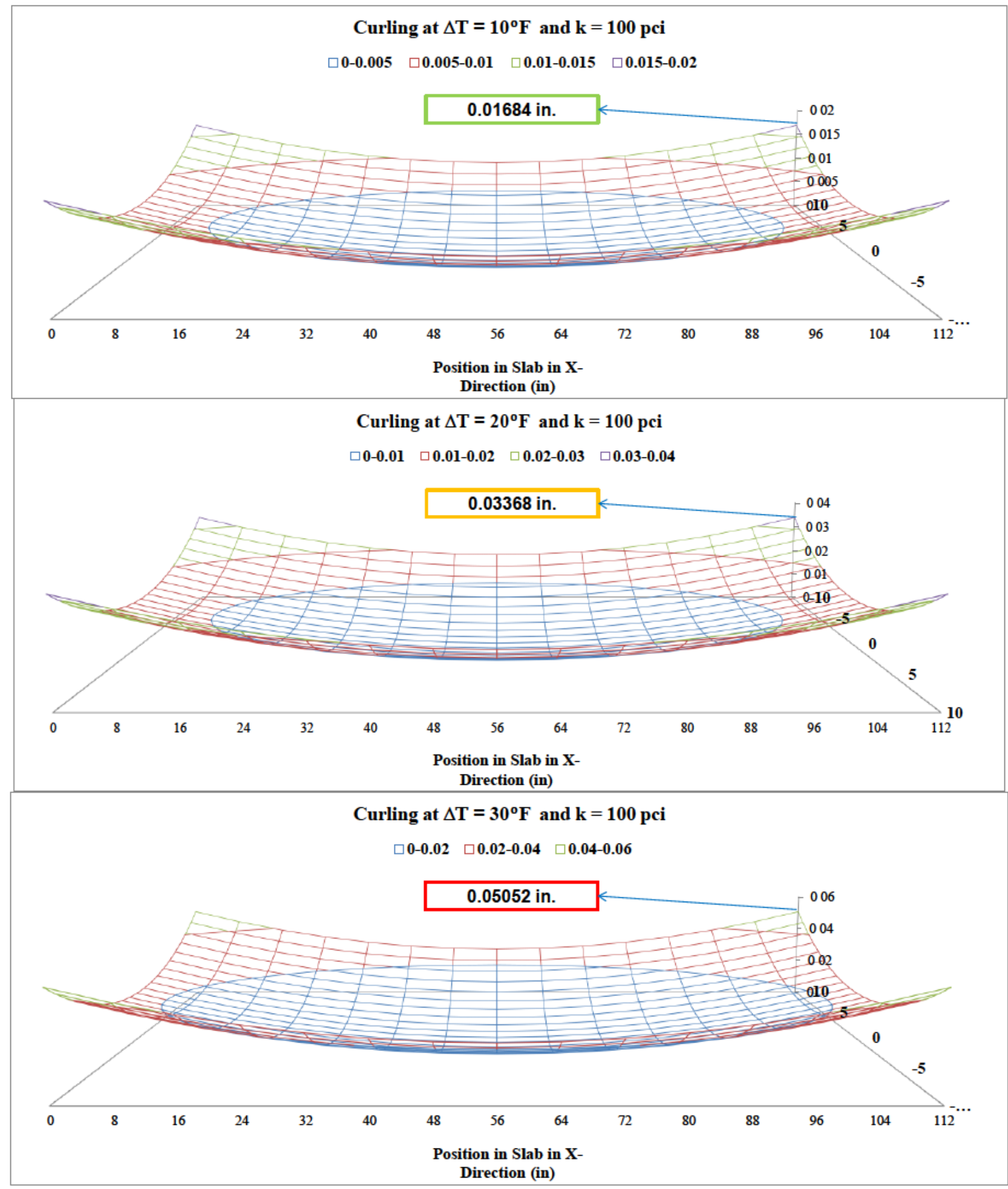

Figure 10: Curling at the same $\mathrm{k}=100 \mathrm{pci}$ with different $\Delta \mathrm{T}\left(10^{\circ} \mathrm{F}, 20^{\circ} \mathrm{F}\right.$, and $\left.30^{\circ} \mathrm{F}\right)$ 


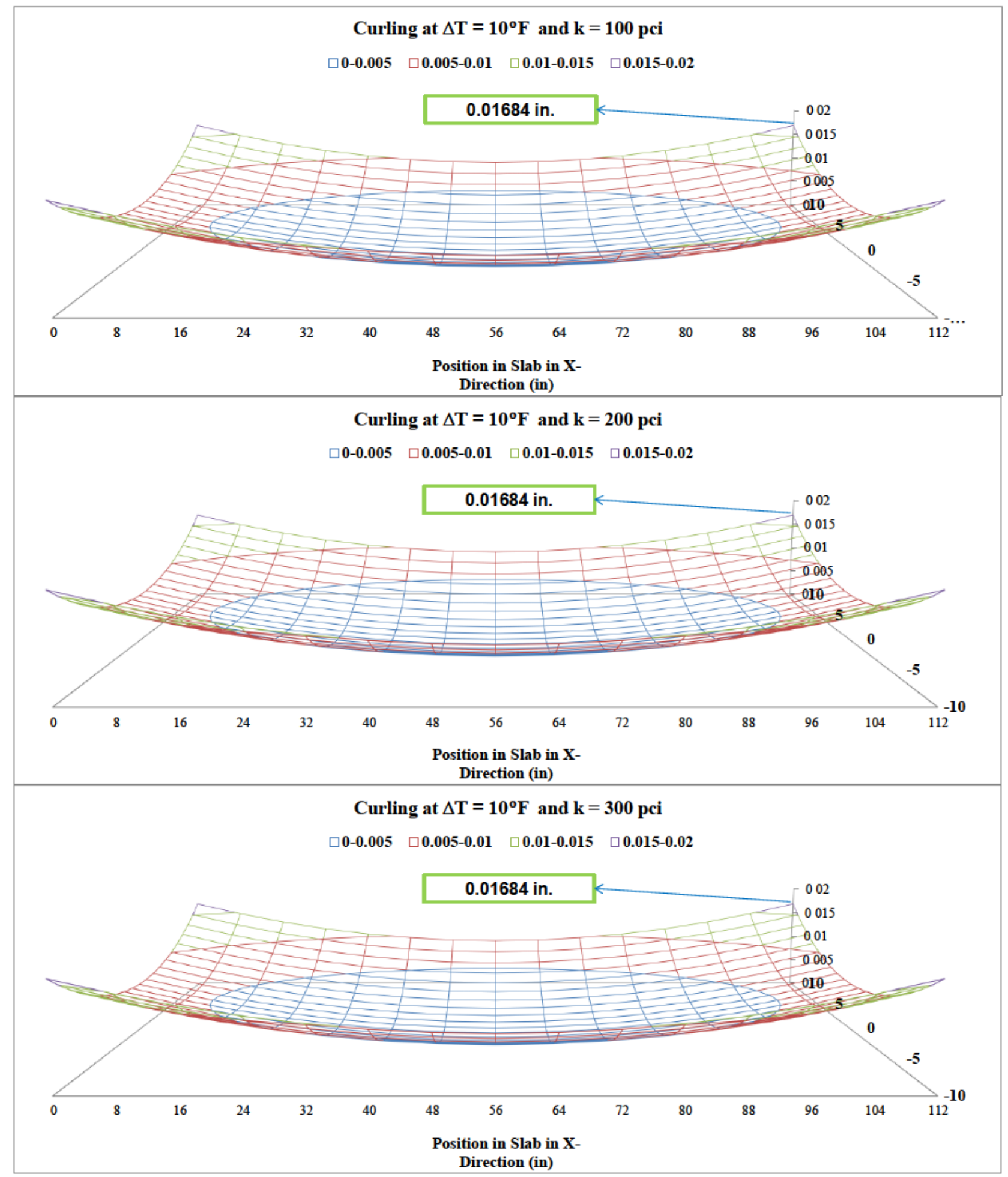

Figure 11: Curling at the same $\Delta \mathrm{T}=10^{\circ} \mathrm{F}$ with different $\mathrm{k}$-value $(100,200$, and $300 \mathrm{pci})$ 


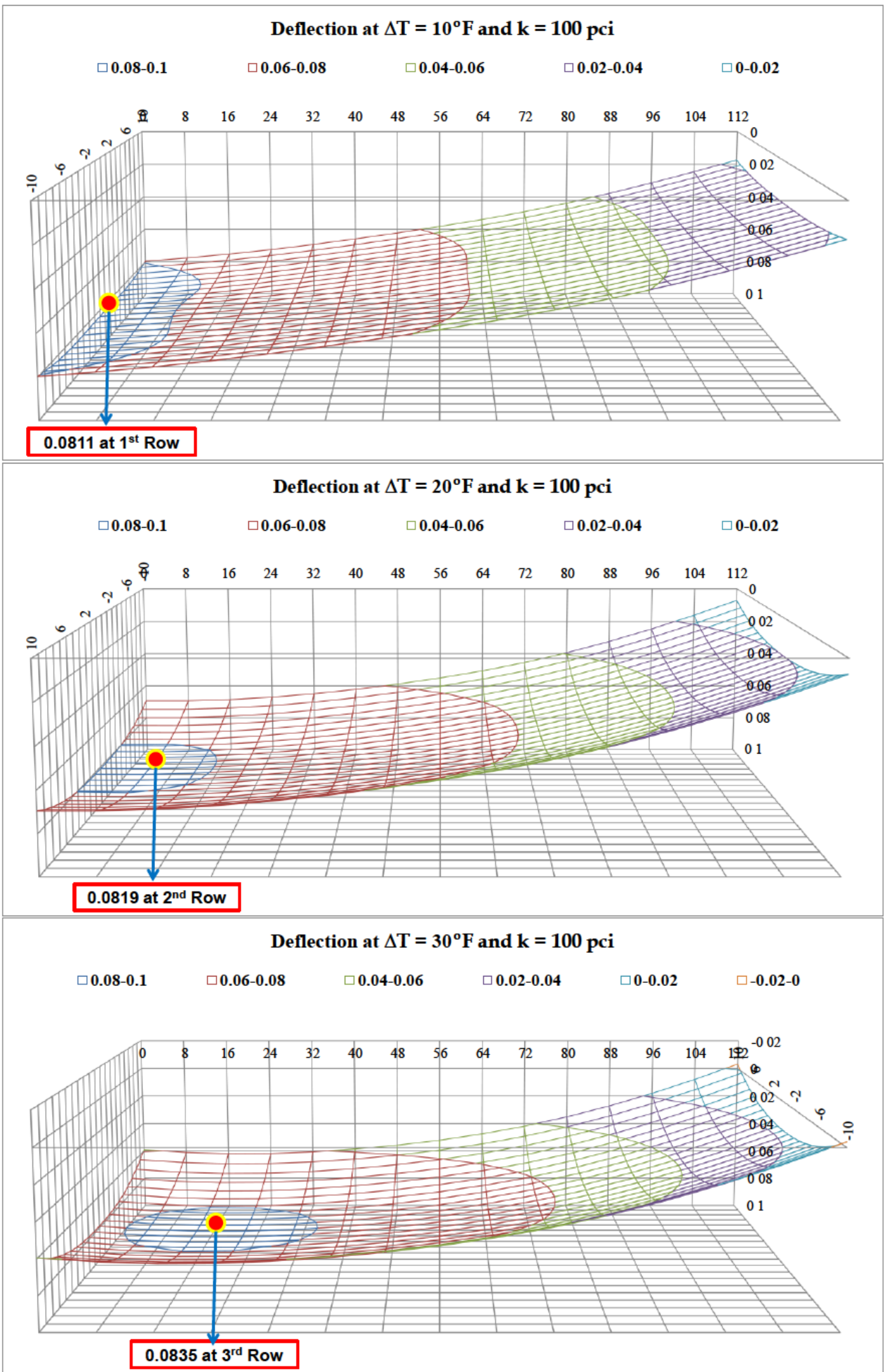

Figure 12: Deflection at the same k-value $=100 \mathrm{pci}$ with different $\Delta \mathrm{T}$ 


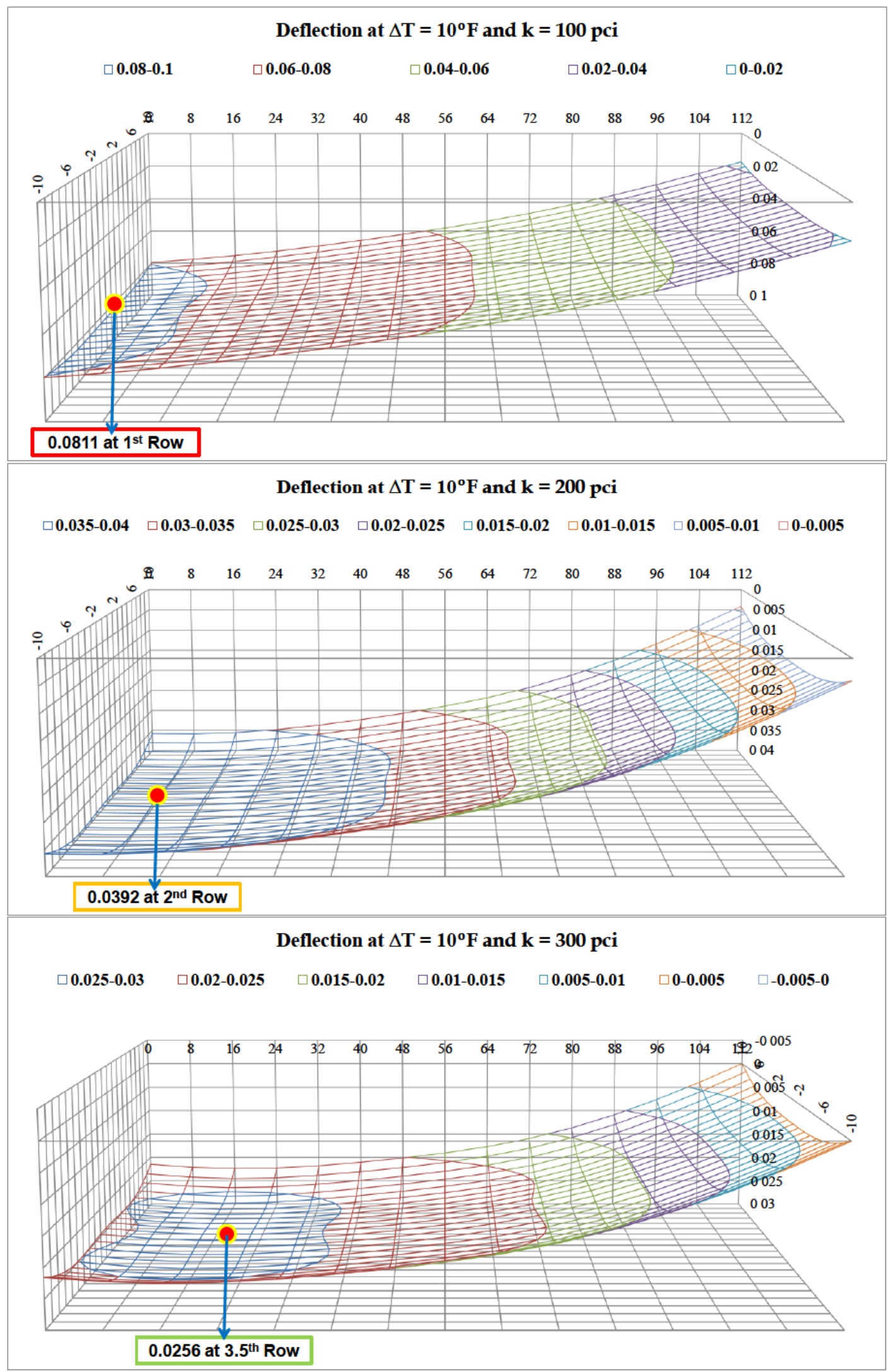

Figure 13: Deflection at the same $\Delta \mathrm{T}=10^{\circ} \mathrm{F}$ with different $\mathrm{k}$-value 
deflection to decrease from 0.0819 inch in the $2^{\text {nd }}$ row to 0.0409 inch in the $4^{\text {th }}$ row (a reduction of $50 \%$ ). Then, an increase in the k-value from 200 pci to 300 pci reduced deflection from 0.0409 inch in the $4^{\text {th }}$ row to 0.0285 inch in the $5.5^{\text {th }}$ row (a reduction of $30.3 \%$ ). Lastly, a curling temperature of $30^{\circ} \mathrm{F}$ and an increase in the k-value from 100 pci to 200 pci led to reduced deflection, i.e. from 0.0835 inch in the $3^{\text {rd }}$ row to 0.0444 inch in the $5.5^{\text {th }}$ row (a reduction of $46.8 \%)$. Then, an increase in the k-value from 200 pci to 300 pci reduced deflection from 0.0444 inch in the $5.5^{\text {th }}$ row to 0.0322 inch in the $6^{\text {th }}$ row (a reduction of $27.5 \%$ ). Based on the foregoing, it is evident that as the k-value rises, the shape of deflection visualization has a greater curve both in $\mathrm{X}$ and $\mathrm{Y}$ direction, while the position of the highest deflection shifted towards the center of the slab.

Table 4 shows the summary of the critical deflection point in each combination. It can be concluded that unlike curling temperature that has a minor effect, the modulus of subgrade reaction exercises a significant effect on deflection.

Table 4: Comparisons of deflection (inch) and its node row position

\begin{tabular}{cccc}
\hline $\mathbf{k} \boldsymbol{\&} \mathbf{\Delta} \mathbf{T}$ & $\mathbf{1 0 ^ { \circ }} \mathbf{F}$ & $\mathbf{2 0 ^ { \circ }} \mathbf{F}$ & $\mathbf{3 0 ^ { \circ }} \mathbf{F}$ \\
\hline $100 \mathrm{pci}$ & $0.0811(1)$ & $0.0819(2)$ & $0.0835(3)$ \\
$200 \mathrm{pci}$ & $0.0392(2)$ & $0.0409(4)$ & $0.0444(5.5)$ \\
$300 \mathrm{pci}$ & $0.0256(3.5)$ & $0.0285(5.5)$ & $0.0322(6)$ \\
\hline
\end{tabular}

Although there are other finite element programs such as three-dimensional finite element programs NIKE3D and ABAQUS [50, 51] used to design and analyze pavement thickness, the output of KENPAVE program is only the values of curling and deflection at the nodes. Therefore, this paper briefly describes research on the optimization of the KENPAVE program output by visualizing the curling and deflection behavior in a three-dimensional shape.

\section{Conclusions}

Based on the results obtained in this study, the following conclusions can be drawn. A higher modulus of subgrade reaction and curling temperature lead to higher stress on rigid pavement. Moreover, curling temperature has more significant impact compared to the modulus of subgrade reaction in maintaining stress in rigid pavement. Curling is not affected by the subgrade quality, but it significantly depends on the temperature differential. A higher temperature differential will result in higher curling behavior and more significant deflection that has a greater curve shifting more towards the center of the slab. On the contrary, a higher modulus of subgrade reaction causes smaller deflection, but still has a more significant curve shifting more towards the center of the slab.

\section{References}

[1] Del Carpio JA, Marinoski DL, Trichês G, Lamberts R, de Melo JV. Urban pavements used in Brazil: characterization of solar reflectance and temperature verification in the field. Sol Energy. 2016;134:72-81.

[2] Solecki WD, Rosenzweig C, Parshall L, Pope G, Clark M, Cox J, et al. Mitigation of the heat island effect in urban New Jersey, Global Environ. Change Part B: Environ. Hazards. 2005;6(1):39-49.

[3] Romeo C, Zinzi M. Impact of a cool roof application on the energy and comfort performance in an existing non-residential building: A Sicilian case study. Energy Build. 2005;6(1):39-49.

[4] Hui L. Pavement materials for heat island mitigation, Chapter 4 - Reflective Pavements and Albedo. Des. Manage. Strategies, 2016, 47-78.

[5] Santamouris M, Gaitani N, Spanou A, Saliari M, Giannopoulou K, Vasilakopoulou K, et al. Using cool paving materials to improve microclimate of urban areas - design realization and results of the flisvos project. Build Environ. 2012;53:128-36.

[6] Qin Y, Hiller JE. Modeling temperature distribution in rigid pavement slabs: impact of air temperature. Constr Build Mater. 2011;25(9):3753-61.

[7] Santamouris M, Synnefa A, Karlessi T. Using advanced cool materials in the urban built environment to mitigate heat islands and improve thermal comfort conditions. Sol Energy. 2011;85(12):3085-102.

[8] Joshi AP, Mehta YA, Cleary D, Henry S, Cunliffe C. Load transfer efficiency of rigid airfield pavement relationship to design thickness and temperature curling. Transp. Res. Rec. J. Transp. Res. 2012;2300(1):68-74.

[9] Al-Abdul Wahhab HI, Balghunaim F. Asphalt pavement temperature related to arid Saudi environment. J Mater Civ Eng. 1994;6(l):1-14.

[10] Arora MG, Al-Tayyib AJ, Al-Mana Al, Ramadhan R. Portland cement concrete apron pavement design study for King Fahd International Airport in Saudi Arabia, Proceedings of the Airfield Specialty Conference, Airport Pavement Innovations: Theory to Practice, Vicksburg, MS, 1993, 216-231.

[11] Ramadhan RH, Al-Abdul Wahhab HI. Temperature variation of flexible and rigid pavements in eastern Saudi Arabia. Build Environ. 1997;32(4):367-73.

[12] Nguyen H, Pham CT, Pham DL, Pham TA, Pham DP, Pham BT. Designing of concrete pavement expansion joints based on climate conditions of Vietnam. J Mech Behav Mater. 2019;28(1):62-7.

[13] Hoang LN, Le TH. Effect of aggregate gradation on rutting of asphalt concrete by using a wheel tracking device in Vietnam. J Mech Behav Mater. 2018;27(5-6):1-6.

[14] Mackiewicz P. Thermal stress analysis of jointed plane in concrete pavements. Appl Therm Eng. 2014;73(1):1169-76.

[15] Ullidtz P. Pavement analysis development in civil engineering. Elsevier Science; 1987. p. 19. 
[16] Sharifi NP, Mahboub KC. Application of a PCM-rich concrete overlay to control thermal induced curling stresses in concrete pavements. Constr Build Mater. 2018;183:502-12.

[17] Williamson RH. Effect of environment on pavement temperature, Proceedings of Third International Conference on Structural Design of Asphalt Pavements, Michigan, 1977, 1, 144-157.

[18] Domenichinin L, Marchionna A. Influence of stress range on plain concrete pavement fatigue design, Proceedings of the Second International Conference on Structural Design of Asphalt Pavements, Purdue University, IN, 1981.

[19] Shoukry SN, William GW, Riad MY, Prucz JC. Effect of FWD testing position on modulus of subgrade reaction. Appl Mech Mater. 2014;518:53-9.

[20] Siddique ZQ, Hossain M, Meggers D. Temperature and curling measurements on concrete pavement, Proceedings of the 2005 Mid-Continent Transportation Research Symposium, lowa State Univ, 2005.

[21] Hernandez J, Al-Qadi IL. Closed-Form solution for curling responses in rigid pavements. J Eng Mech. 2019;145(2):04018133.

[22] Westergaard HM. Stresses in concrete pavements computed by theoretical analysis. Public Roads. 1926;7:25-35.

[23] Westergaard HM. Analysis of stresses in concrete due to variations of temperature, Proceedings of the 6th Annual Meeting Highway Research Board, 1927, 6, 201-215.

[24] Hiller JE, Roesler JR. Simplified nonlinear temperature curling analysis for jointed concrete pavements. J Transp Eng. 2010;136(7):654-63.

[25] Teller LW, Sutherland EC. The structural design of concrete pavements, Part 2: observed effects of variations in temperature and moisture on the size, shape and stress resistance of concrete pavement slabs. Public Roads. 1935;15(9):169-97.

[26] Mirambell E. Temperature and stress distributions in plain concrete pavements under thermal and mechanical loads, Proceedings of the 2nd International Workshop on the Design and Rehabilitation of Concrete Pavements, 1990, 121-135.

[27] Ioannides AM, Salsilli-Murua R. Temperature curling in rigid pavement: an application of dimensional analysis. Transp Res Rec. 1999;(1227):1-11.

[28] Choubane B, Tia M. Analysis and verification of thermal-gradient effects on concrete pavement. J Transp Eng. 1995;121(1):75-81.

[29] Mohamed AR, Hansen W. Effect of nonlinear temperature gradient on curling stress in concrete pavements. Transp Res Rec. 1997;1568(1):1568.

[30] O'Mahony MJ, Ueberschaer A, Owende PM, Ward SM. Bearing capacity of forest access roads built on peat soils. J Terramechs. 2000;37(3):127-38.

[31] Mulungye RM, Owende PM, Mellon K. Finite element modelling of flexible pavements on soft soil subgrades. Mater Des. 2007;28(3):739-56.

[32] Aure TW, Ioannides AM. Curling effects on concrete slab-on-grade fracture. Mater Struct. 2016;49(8):2991-3004.

[33] Kim S, Ceylan H, Gopalakrishnan K. Finite element modeling of environmental effects on rigid pavement deformation. Front Struct Civ Eng. 2014;8(2):101-14.

[34] Byrum CR, Ye D. Evaluating the effect of concrete slab curling on joint load transfer responses. Transp Res Rec. 2012;2305(1):4353.
[35] Zhang Q, Sun Y, Li J. Analysis on void beneath curling slab in rigid base cement concrete pavement and fatigue life prediction. Appl Mech Mater. 2012;204-208:1782-8.

[36] Setiawan DM, Rahmawati A, Setiawan IB. Perbandingan tebal dan analisis kerusakan perkerasan lentur menggunakan program kenpave dan metode asphalt institute. J. Ilmiah Semesta Teknika. 2018;21(2):106-13.

[37] Dinata DI, Rahmawati A, Setiawan DM. Evaluasi tebal perkerasan lentur dengan metode analisa komponen dari Bina Marga 1987 dan metode AASHTO 1993 menggunakan program KENPAVE (studi kasus: jalan karangmojo-semin sta 0+000 sampai sta 4+050). J. Ilmiah Semesta Teknika. 2017;20(1):8-19.

[38] Tabatabai AM, Barenberg EJ. Finite-element analysis of jointed or cracked concrete pavements. Transp Res Rec. 1978;671.

[39] Korovesis GT. Analysis of slab-on-grade pavement systems subjected to wheel and temperature loadings, Ph.D. Dissertation, University of Illinois at Urbana, Illinois, USA, 1990.

[40] Lee YH, Lee YM. Corner stress analysis of jointed concrete pavements. Transp Res Rec. 1996;1525(1):44-56.

[41] Tayabji SD, Colley BT. Analysis of jointed concrete pavements, Techni. Rep. FHWA-RD-86-041, Federal Highway Administration, McLean, Virginia, USA, 1986.

[42] Chou YT. Structural analysis computer programs for rigid multicomponent pavement structures with discontinuities: WESLIQUID and WESLAYER, Techni. Rep. GL-81-6, U.S. Army Engineer Waterways Experiment Station, Vicksburg, USA, MS, 1981.

[43] Tia M, Armaghani JM, Wu C, Lei S, Toye KL. FEACONS III computer program for analysis of jointed concrete pavements. Transp Res Rec. 1987;1136.

[44] Wu C, Larsen TJ. Analysis of structural response of concrete pavements under critical thermal-loading conditions, Proceedings of the Fifth International Conference on Concrete Pavement Design and Rehabilitation, Purdue University, West Lafayette, Indiana, USA, 1993.

[45] Khazanovitch L, Yu HT, Beckemeyer C. Application of ISLAB2000 for forensic studies, Proceeding of the 2nd International Symposium of 3D Finite Element for Pavement Analysis, Charleston, West Virginia, USA, Des. Res, 2000, 433-450.

[46] Huang YH. Pavement analysis and design. 2nd ed. New Jersey: Pearson/Prentice-Hall; 2004.

[47] Avci B, Gurbuz A. Modulus of subgrade reaction that varies with magnitude of displacement of cohesionless soil. Arab J Geosci. 2018;11(351):351.

[48] Basudhar PK, Yadav SK, Basudhar A. Treatise on Winkler modulus of subgrade reaction and its estimation for improved soil-structure interaction analysis. Geotech Geol Eng. 2018;36(5):3091-109.

[49] Kim YR. Mechanistic-empirical pavement design guide, Course Material CE472/872: Pavement Design and Evaluation. Department of Civil Engineering, University of Nebraska - Lincoln; 2019.

[50] Mulungye RM, Owende PM, Mellon K. Finite element modelling of flexible pavements on soft soil subgrades. Mater Des. 2007;28(3):739-56.

[51] Wang QF, Chen Y. Improvements to modeling of concrete slab curling by using NIKE3D finite element program. Transp Res Rec. 2011;2226(1):71-81. 